AN INUESTIGATION ON THE EMISSIONS IN A TORCH CHAMBER S.I.E. BY

M. M. Arad, A.A.Desoky and A.Abdelkhalek

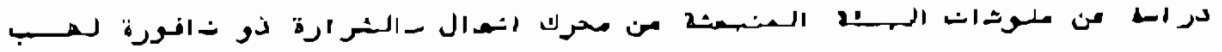

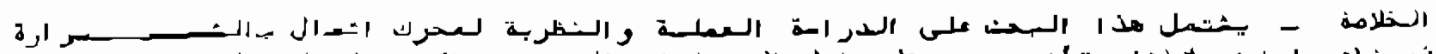

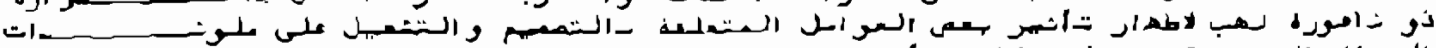

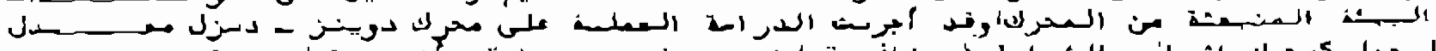



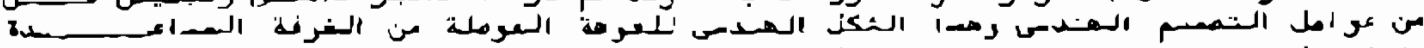



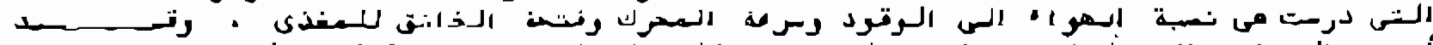

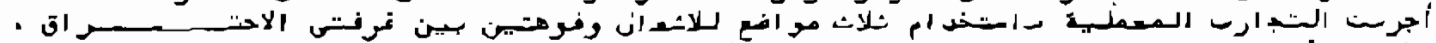

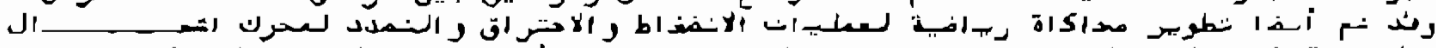

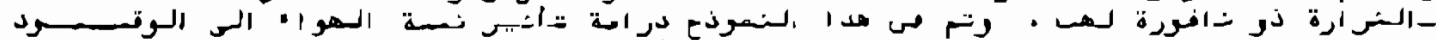



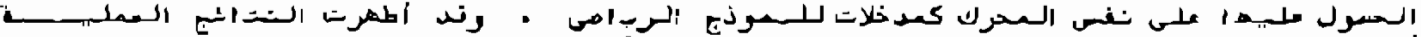



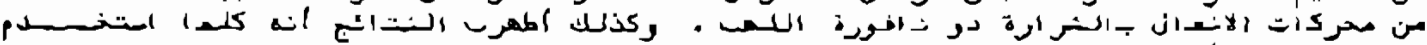

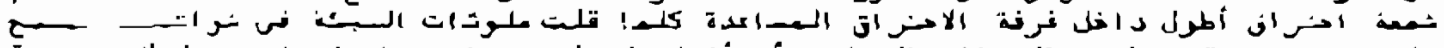

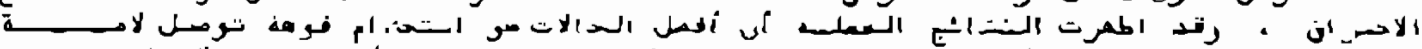

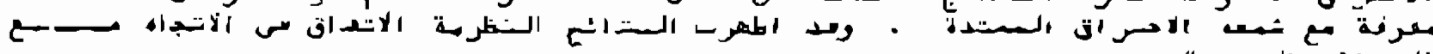
ACSTRACT

Experimental and theoretical investigations vere made on a torch chamber jpark lgnjtion englne to determine the effect of some deslgn and operational parameters on engine emissions. The experimental study was performed usinq a modifled Deutr-biesel engine developed to De a torch chamber apark ignition engine. During this investigation, two main design paraneters vere investigated namely, the connecting passage shape and the flame laitlation point. In this work three ignition point location and two different connecting fassage shapes vere investigated over a wide range of mixture strength, engine speed and throttle opening. A mathematical model of compression, combustion and expansion processes of the torch shamber spark lgnition engine has also been developed. This model aims at estimating the effect of mixture strength on the No and co rates of Eormation in this englne. In developlng the model, experimental data obtalned on the sane engine gre used. The expezimental results reveale that, the configuration of she conrecting passage has a great efect on emissions from the torch chamber S.I.E. It aiso reveals that, as the spark plug 15 extended inside the combustion chanber, englne emissiona decrease: The optimum case is reached when using a convergent divergent passage coupled uth the extended spark plug. The tzends obcalned from the. mathematlcal slmulation are in a good agreement vith the experimental one.
\end{abstract}

\title{
LIATRODUCTION
}

Air pollution is one of the great problems that appeared in the last $E$ ev years. Internal combustion engines are considered to be one 
of the main sources of pollutants, especially the conventional S.I.E. The major air pollutants found in the exhaust of the conventional 5.I.E. are, Nox, Co, and HC. Many Investigatorg try to elnd out a new combustion technlque that minimizes exhaust emlssions and glves a good Euel economy. This can be done if the new combugtion technique achleves the following conditiong.

1-Hlgher compression ratio vithout detonation.

2-Hlgher combustion efficlency.

3-Extended lean mistre $11 \mathrm{mlt}$.

4-Low combustion temperature so that, Nox formation may not increase and majntaining lov CO and HC.

It is known that operating the engine at higher compression ratio, vill increase the tendency to detonate. We are confronted with the problem that, operating the engine at lean mixture will decrease combustion rate due to relatively lou temperature and increased cycle variations. Engines operating at high compression ratios vith lean mixtures are inherentiy likely to lead to increased Nox emissions associated vith the higher oxygen avallable and higher mean temperature levels $(1)$.

To overcome the difficulties assoclated vith lean burning in S.I.E., it is necessary to lncrease combustion rates and lmprove ign!tion performance. This can be done by improving and enhancling the degree of turbulence vithin the combustion chamber at the combustion time[2]. It is necessary to gtrengthes the mixture near the lgnition point using the technique of torch chamber englne.

combustion characteristics and engine performance of torch chamber S.I.E. das studied by Mbas(3). He investlgated the effects of connecting passage shape and spark gap projection on engine performance and combustion characteristics. He found that using the convergent divergent passage coupled vith the extended spark gap projection will improve engine performance. He found also that the lean misfire 1 imit (LHL) of stable operation of the englne is dependent on the connecting passage shape and less sensltive to the location of the lgnition point.

Flame photographs have been recorded by sinnamon and cole(4) during their investigation of divided chamber jet lgnition englne. The photographs have revealed that, the torch jet uhich ruches from the prechamber causes a large increase. in turbulence intensity and in the rate of mixing in the main chamber. The analysis indicates that, thls torch jet induced turbulence is responsible for a large increase in the Inltial mass rate of burning and, as a result, shortening of burn interval.

Many investigations have been done by Adams 5,6$)$ on the torch chamber S.I.E. to study the generating of combustion turbulence, optimum torch chamber volume and orifice diameter. He also computed the combustion vave thickness, turbulence characteristics time and the effect of nozzle orientation on combustion rate, engine performance and engine emlssions. A prechamber, named the turbulence generated pot (TGP), vas developed by Noguchl et all7) to extend the effective LML and to increase Elame propagation velocity. They found that these parameters are depending on the configuration of the TGP and also on the spark flug location. They also proved that when the fet flame from 
the TGP createg a strong turbulence in the main chamber, the result will bc a high flame speed and a reduction in Nox emissions.

The present vork ains to study the torch chamber as a means of controliing engine exhaust emissions. This work lnveatigates the effect of tlame initiation polnt, connecting passage shage and other englne operating parameters chat affect engine exhaust emissions. The experimental vork is directed to clarify the effect of the above mentioned parameters on the englne emissions. A mathematical model has also been developed to study the effect of equivalence ratlo on englne enisslone. A comparison betueer calculated and measured Nox and co trends are made and discussed. The results presented in this paper and more detaileld of the experimental procedure are from referencel 8 ).

\section{2-EXPERIMENTAL SETUP AND RROCEDURES}

The experlments were carried out at the Army Research Center. Fig.(1) shows a schematic d lagram for the experimental setup. It vas built to verify the possibilities of variation of connecting passage shape, spark gap projection and engine operating conditions. The setup also verified accurate measurements of engine data and exhaus emissions. The engine used $i s$ a modified Deutz-Dlesel engine. It is a four stroke, four cylinder, overhead valves, air cooled with a $11 \mathrm{~cm}$. bore, $14 \mathrm{~cm}$. stroke and with a swlrl chamber in the cyllnder head. It is modified to be a torch chamber s.1.E. with compressinn ratlo of $9: 1$.

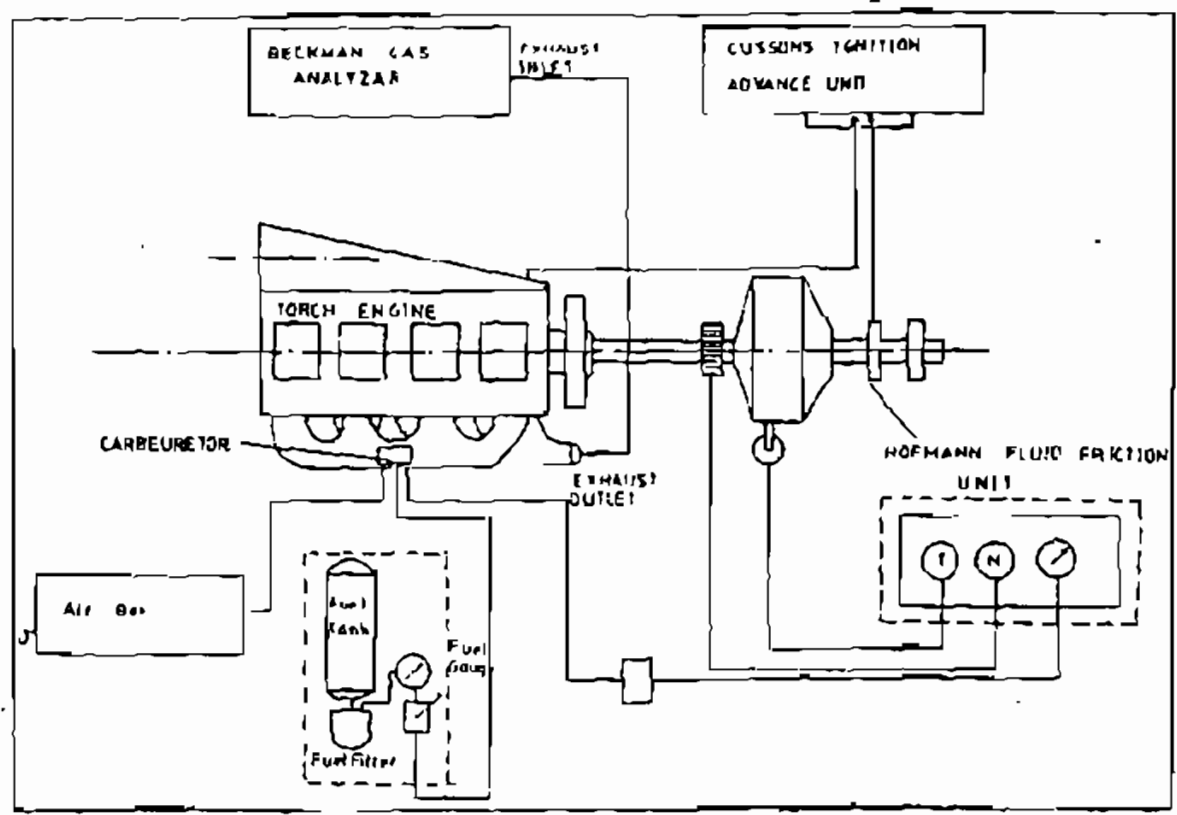

Fig. (1) Sohematis Diagram of The Experimental get-up

The intake manifold was modified to achieve unicorm mixture distribution betveen cylinders. So a new one was provided to the engine 
A. 80 M.M. Awad, A.A. Desoky and A. Abdelkhalek

having a central positlon for the carburetor and it was adopted to be fitted vith an electric heating for the charge and controlling the charge temperature to be 30 oC 2 . A conventional carburetor was selected according to the engine air flow requirement at extreme condition. An adjustable needle value was fitted to the origlnal maln-jet nozzle to control manually the mlxture strength.

The englne vas modified to be a $B . I$.E. A conventlonal spark ignition system vas used. The distrlbutor used lg of contact breaker type and provided with a centrifugal and vacuum spark advance uhich assists rapid setting of optimum lgnition thming. Three spark plugs ulth ditferent electrode lengths vere used. The electrode lengths used were $3.5,8$ and $13 \mathrm{~mm}$. The thlid one was developed for this rork. The modifled cylinder head is shoun in Fig.(2).1t consists of unscavenged spherical shaped sulel chamber casted in the cylinder head vith 28.22 cc volume which represents $34.7 \%$ of the clearance volume (after modiflcation). It is connected to the main chamber vith a cylindrical straight passage of $9 \mathrm{~mm}$.d lameter, $20 \mathrm{~mm}$. length and 300 inclination to the piston croun. It is fltted uith a spark plug in the original location of the heating plug. Tro different connecting passage shapes vere used, the original cylindrical one and $\dot{c}^{N}$ convergenc divergent nozzle vith a $9 \mathrm{~mm}$. throat and 190 divergent angle. Fig.(3) shous the confiqui ations of the two connecting passage used.
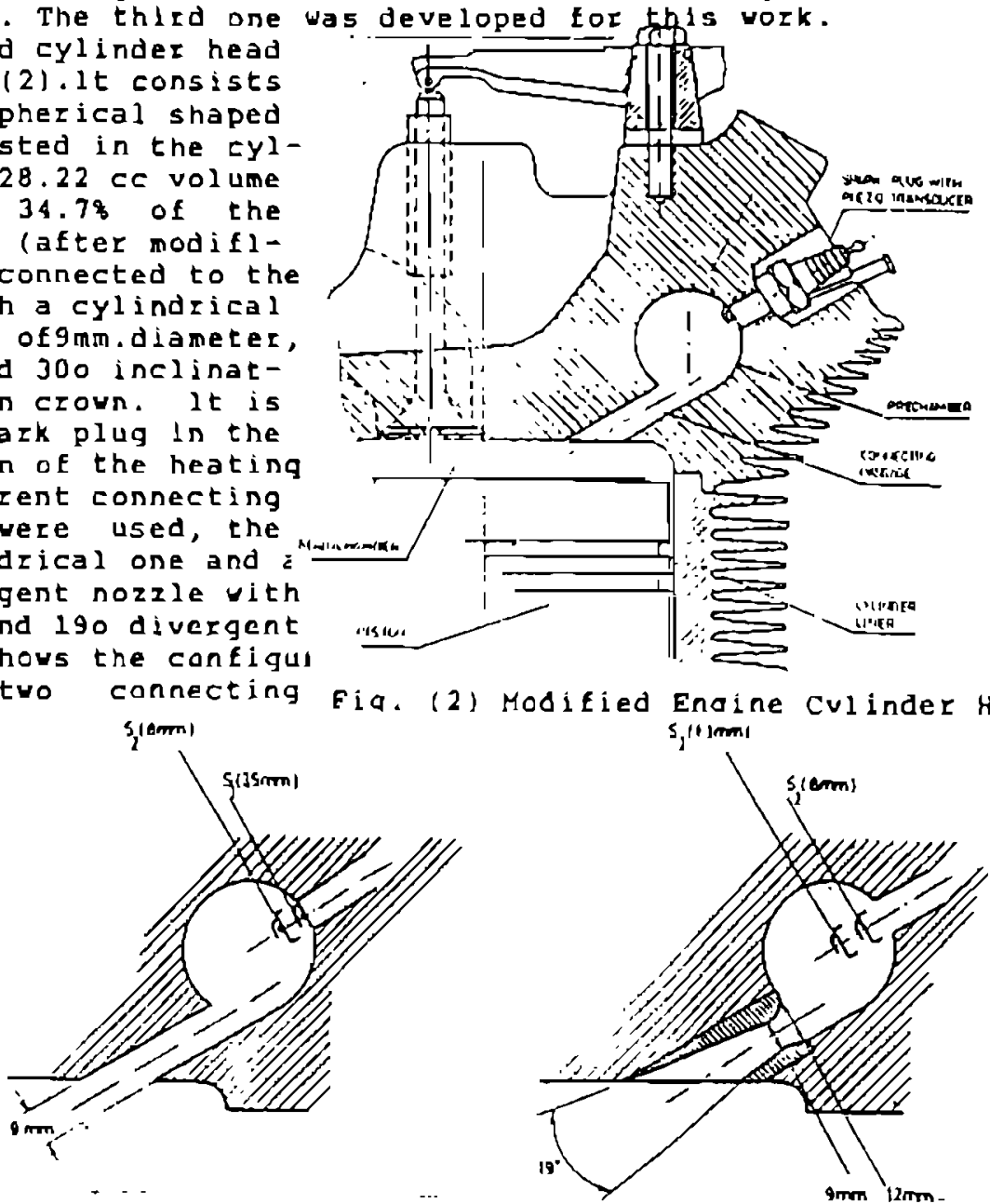

Fig. (3) Prechamber Combination To Be Tested





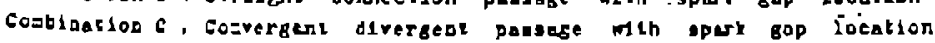
cosblation D. Cosergint divergent pasage fib spart sap location 
Englne speed vas monltored directly from a pagnetle plek-up in connection with a 60 tooth gear vheel lixed on the dynamometer Input shaft. The engine targue vas measured by a tluld exletion dynamometer having maximum capacity of $715 \mathrm{kp} . \mathrm{m}$ and maximum gped of $6000 \mathrm{IPn}$. The percentage of throttle opering vas dieplayed by meane of analogue indlcator. The exhaust gas temperature vas measured ualing a chromalumel thermocouple lixed on the exhaust manleas, attached to and logue indicator. Engina exhaust emlostons vere meacured using Beckman gas analyzers. The systed is sultable for analyzing hot exhaugt gases. The gases unlch con be analyzed are $\mathrm{CO}, \mathrm{CO}, \mathrm{NOX}, \mathrm{HC}$, and 02 . The HC en!gsion is anglyzed at 180 oC (dev polnt $=2700 \mathrm{C}$ ).

To cuver the experimenta: Lnvestlgatlons, the mixture strength vere changed trom $x$ ich $(\phi=1.2)$ to leanmiglire 1 mit. Englne speed vas changed Erom 1000 to 2200 rpre. The testg vere classlelad Into tro serles. In the first earles of tests, stralght passage vas used coupled ulth the cyllnder head arrangements $A$ and $B$, Fig.(3). Hhile In the second serleg of tests the convergent divergent nozzle vas uged coupled with the arrangements $C$ and D, Fig. (3).

\section{EXPERTMENTAL RESULTS AND DISEU5SIONS}

The results of the eests are collected and dsplayed grophlcally as Eour familles of curves. For each comblnation A, B,CsD, (Fig.13), engine emisslons of Nox, Co and KC are meaaured and recorded for d!sferent operating condlelons. Shoun in these famllies of curves are the effect of equivalonce ratlo, bmes, enqine speed and throttle opening on englne emisslons. The test englne vas adopted for optimum ignition advance all-over the tests.

Shoun in Slg5. (4)through(5) are comparatlve curves of enqine emigsians of Yox, CO and HC as a Eunctlon of equjvalence zatia at Eul throttle, vaziable load and engina speed of $1000 \mathrm{rpm}$. it is cleaz from these flgures that the increase of spark gap projection tends to decrease englne emisslons of Nox, Co and HC, comparing combinatlon with $B$ and $C$ with $D$. The same advantages apppar whan using lean nixture
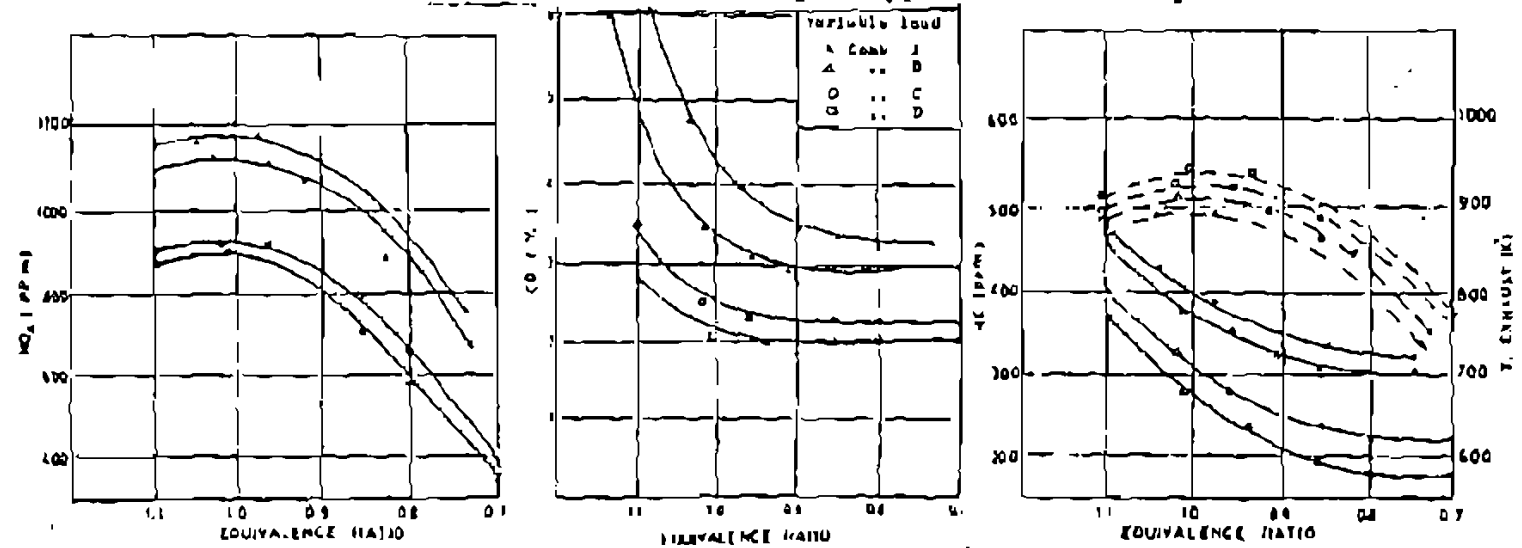

Flgs. (d)throughig) Englne Emlssions as a Functson of Equlvalence " Ratlo At Engize speed $1000 \mathrm{rgn}$ 
M. 82 M.M. Awad, A.A. Desoky and A. Abdelkhalek

The convergent divergent passage has the same advantages, comparing combination $B$ with $D$. Combination $D$ satigfies the lover engine emisslons all-over equivalence ratios examlned. The relative galns obtalned visen using combination D instead of $A$ has been notlced to increase as the mixture becomes leaner. It is also clear from the results that using convergent divergent passage makes it possible to run the engine at relatively lean mlxture, $\phi=.7$ with less exhaust enisslons.

Flgs.(7)through(9) show the effects of bmep on engine emissions when using lean mixtures, $\phi=. \theta$ and 0.7 . It is clear from these figures that as bmep lncreases Nox increases vhlle CO and HC decreases. It can be also seen that Eurther extension of spark gap projectlon, keepling the bmep constant, lead to decrease engine emissions. The use of convergent divergent pasage has the same advantages. Also use of combination $D$ gives the lower values of engine emissions for all values of bmep tested. The result also show that runnling the englne with convergent divergent passage at leaner mixturp $\phi=7$ lead to a further

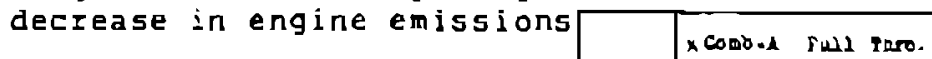


Elgs. (7)through(9) Englne Emisstons is a Function of bmep

The influence of engine speed on exhaust emissions is shown in Flgs. (10)through(12). These relations are recorded at Eull throttle, variable load and at equivalence ratios of $0 . \theta$ and 0.7 . It can be seen from these Eigures that as engine speed increases Nox emlssion increases while CO and HC decrease. It is also noticed that further expanding of the spark gap projection inside the torch chamber, keeping engine speed constant, will decrease engine emissions. The use of convergent divergent passage gives less engine emissions. The relative gain obtained when using combination $D$ instead of A increases as engine speed increases.

Figs.(13)through(15) show the influence of throttle opening on engine enissions. Combination 015 used with full, $3 / 4$, and $1 / 2$ throttle 

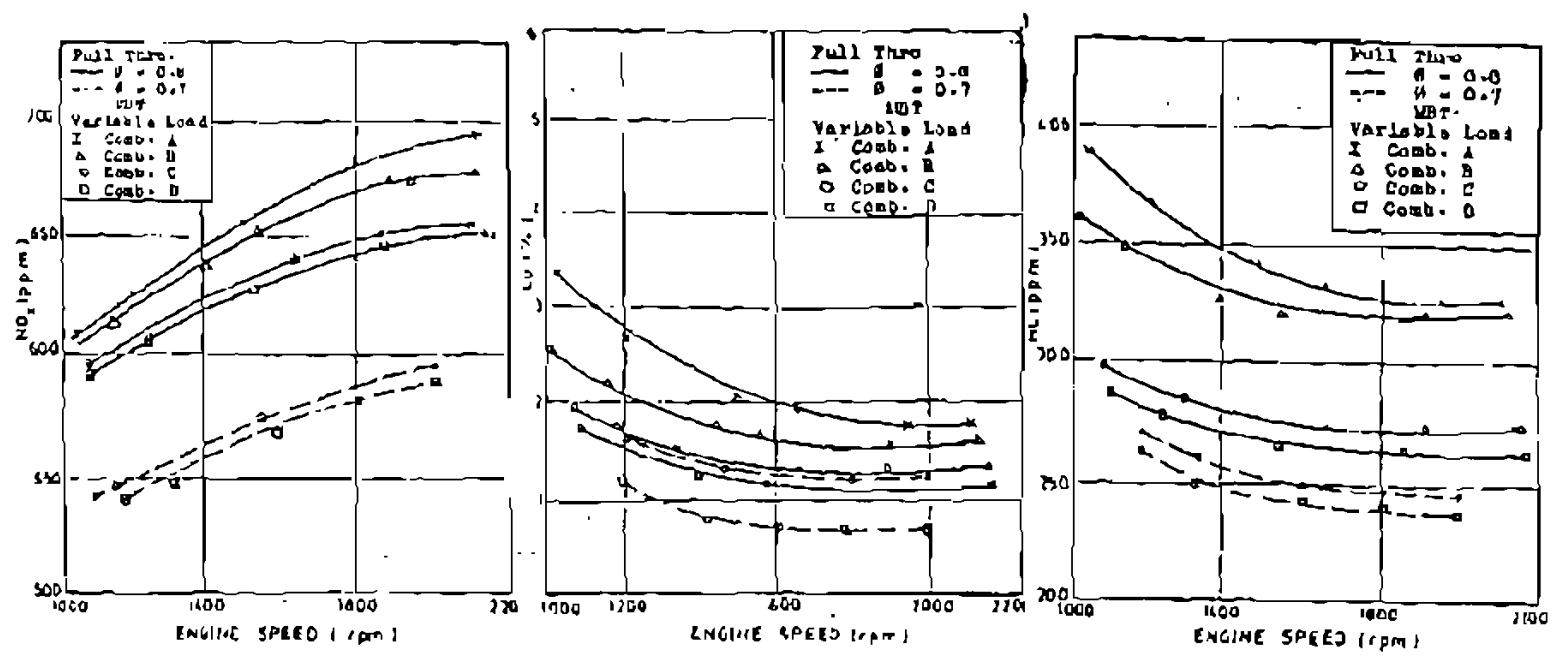

Figs. (10)through(12) Englae Enlssions As a Function of Enclne speed at rull Theotele opeulna


Flgs. (1J)through(15) Englne Emissiong $\lambda$ s a function of throttle Opentro

opening and 0.8 equivalence ratid vith variable engine speed and load. Eig.(13) shov that as the throttle opening is decreased, Nox enission decreases, while Flgs(14)and(15) shou that as the throttle opening ls decrcased the llC and Co emlastong increage.

The results described above demonstrate that the englre exhaust emisslons decrease as the spark gap projectjon extends lrside the torch chamber. Thls may be explained as follous; the spark gap belng extended in the torch. chamber, the omount of unburned inlxture escaping crom che torch chamber Into tle maln chamber during the early stage of combustion are reduced. Using the cxpanded spark plug vill initiate 
M. 84 M.M. Awad, A.A. Desoky and A. Abdelkhalek

the flame kernel approximately in central position, thus a spherical flame development may be obtalned. This may decrease the combustion duration and consequently decrease the unburned mixture escaping via the connecting passage. Moreover, moving the lgnitlon polnt towards the center of the combustion chamber, the residual gas around the spark gap are well scavenged, thls asslsts good lgnitablilty of the mixture and extends the LML. This may be due to the expected $r$ ise in temperature of the center electrode tip. This is Induced by the elongated heat rejection path. Thus, it may be assumed that the LML vas extended due to the decreage in the quenching effect on the flame kernel.

The effect of the geometrical shape of the connecting passage is clarified comparing the results obtained vhen using combination $B$ and C. These results conclude that the use of convergent divergent passage instead of the straight one improves the engine emigslons. This may be due to improved turbulent motion generated by the flov through the nozzle. This result agrees vith the result obtained by shapirolfi. Abas(3) in his experiments on the same engine showed that the use of the convergent divergent nozzle extends the LML, enhance turbulent generation and achieve fascer burning rate. A survey to these results reveals that, the use of convergent divergent passage coupled vith the extended spark gap projection vlll decrease combustlon duration, decrease combustion temperature and enhance turbulent generation. These vill decrease engine exhaust emissions of NOx, CO and $H C$.

The effects of operating parameters examined may be summarized as follovs, it is possible to run the torch chamber S.I.E. at relatively lean mixture vith gains in fuel economy and engine emissions. Thls advantage may be due to, the lncreased turbulence created vith the torch chamber to compensate for the lower burning velocity of the lean mixture, The combustion of lean mixtures vill zesult in lov combustion temperature, which may not support Nox formation vhile malntaining lover $\mathrm{CO}$ and $\mathrm{HC}$ emissions. The influence of engine speed on emissions can be explained as follovs; As the engine speed increases, the mixture turbulence is increased and this will increase the burning rate and good mixing of the tuel and air. Consequently a reduction in $H C$ and Co emissions may results. Also as the engine speed is increases, the peak cylindar pressure lncreases uth a cozresponding lncrease in peak tempezature. This high temperature coupled vith its duration are conductive to NOx formation. The influence of throttle opening is that, as the throttle opening is decreaged Nox decreases vhlle $4 C$ and co jncrease. This may be due to the decrease in bmep and combustion temperature as the throttle opening is decreased. Also the turbulence motion and the combustion rate decreases. These vill tend to decrease Nox and increase co uhile give a chance to guench HC.

\section{4-THEORETILAL ANALYEIO}

The ozimary purpose of the present vork is ta develop a simple combustion model for predicting the pressure and temperature vs crankangle diagrams and the NO and co emissions rate of formatian. The analysis is made by means of the pressure vs crankangle diagram, experimental rate of combustion and optlmum jgnitlon timing unich are measured on the same engine as an input data to the model. In this study the effect of equivalence ratio on No and co rates of formation 
arp examined. The basic kinctic, encrgy and chemlcal equilibrium equations are taken into accourt.

The corch chamber S.I.E. is treated as a two thermodynamic subsystems (pre-and main chambers systems) coupled by mutual mass slow. The vorking fluid prior to ignition ls considered to be a non reacting homogereous mixture of fuel vapor plus air. The. compression process is assuned to be aujabatic. Initgaliy the mixture ls assumed to be at atmospheric fressure and temperature ard a volume of $1496.46 \mathrm{cc}$. ( the cylinder volume). The compression begins at BDC and ls treated in an incremental manner, a 2 degree crankangle lncrement is adopted. Before tne end of this process, the combustion is assumed to start at a specified MaT spark timing. The function of this process is to determine the initial conditions in both systems before combustion.

The combustion erocess stacc when the spark plug 15 fired at MBI spart timing. The process is treated in an incremental manner, a 2 deqree crakangle increment being adopted. Each successive increment in crankangle comprises four steps, as shown. in Fig. (16). These four stegs are;

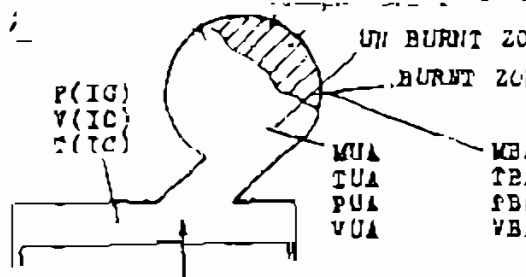

(a)

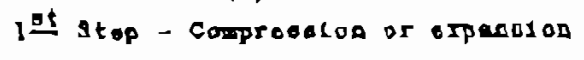
ocruras

- Theraodjuadic Prcportie aro ovaluatod

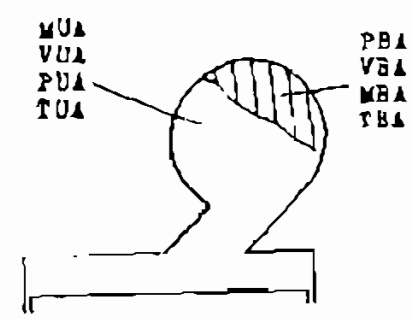

(c)

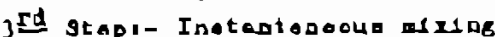
and aqualits or bural zon proportioo

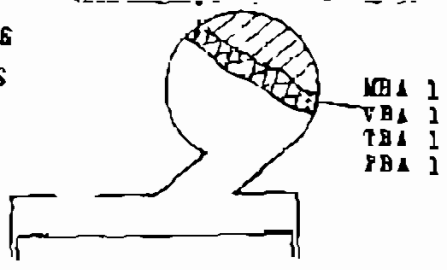

(b)

2 Dd stapi= The plotod Stopo Corbution occared

- gotimate (T)edlebatic and Chomlenl Compooltion of Product

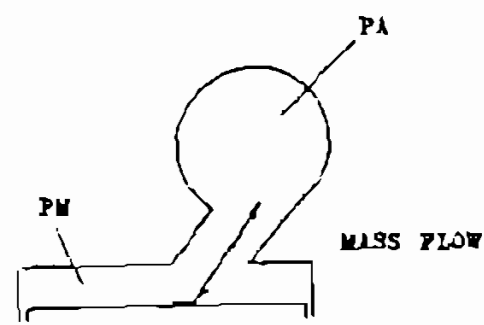

(d)

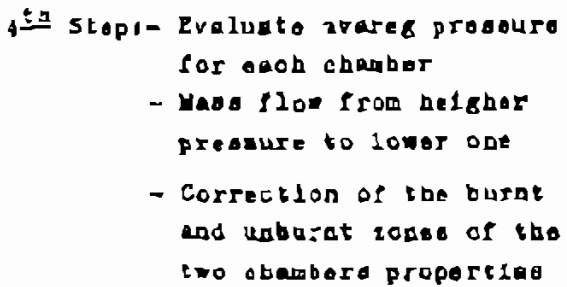

two oberbera properciag

Eig. (16) Analysis of Combustion Process where;

HUA, TUA, PUA and VUA are mass, temperature, pressure and volune of unburnt gas in the prechamber, MBA, TBA, PBA and VAA are mass temperalure, pressure and volude of burnt gas, 
1-Compression or expansion occurs as the piston moves up or down-ward. Thermodynamic properties of the gases in both systems are evaluated. 2-At the spark timlng, combustion occurs in a specifled fraction of the mixture. The adiabatlc flame temperature and the chemlcal equilibrium of the product species of $\mathrm{CO}, \mathrm{CO} 2, \mathrm{O} 2, \mathrm{H} 2, \mathrm{H} 2 \mathrm{O}, \mathrm{OH}, \mathrm{H}, \mathrm{O}, \mathrm{N}$ and $N 2$ are calculated.

3-Instantaneous mixing of the total burnt zone is allowed and average pressure and temperature are evaluated.

4-An aqui-steady mass flou through the connecting passage as a result oE the pressure difference between the two systems is allowed, then a correction is made Eor the thermodynamic propertles.

The new adlabatic tlame temperature of the burnt zone is calculated and the rate of No and co formation is estimated. This process ends when all the mass of the reactant are burned early in the expansion pracess.

The expansion process is assumed to be adiabatic and is treated in on incremental manner, a 2 degree crankangle increment is again adopted. The process starts at TDC and ends at the time of exhaust valve opening. During this process and after the combustion ends, each crankangle increment comprises two steps. These two steps are, expansion due to piston motion, followed by mass flow through the torch opening. The rate of No and Co formations are predicted taking into account the flux transfer through the torch opening. The combustion gases are assuined to be in chemical equilibrium at the appropriata pressure and temperature.

The kinetic mechanism proposed for No calculation is the extended 2eldovish nechanusm which comprises the following reactions(10);

$$
\begin{aligned}
& \mathrm{N}_{2}+\mathrm{O}==\mathrm{NO}+\mathrm{N} K \mathrm{~K}=1.4 * 10 * \pm 14 \exp (-37900 / \mathrm{RT}) \mathrm{cc} / \mathrm{mol} . \mathrm{sec} \text { (1) } \\
& 02+N===N O+O K 2=6.4 * 10 * 7 \exp (-3140 / R T) \quad \mathrm{cc} / \mathrm{mol} . \mathrm{sec}(2) \\
& \mathrm{N}+\mathrm{OH}==\mathrm{NO}+\mathrm{H} \quad \mathrm{K} 3=4 * 10 * * 13
\end{aligned}
$$

The rate of No formation is predicted using the following relation taking Into account the flux due to mass flow through the torch opening;

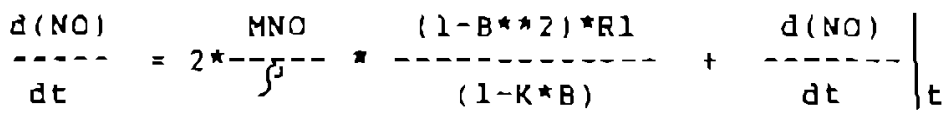

Where; MNO is the molecular weight of NO, is the gas denslty=pV/RT, $B=N O / N O E, \quad K=R 1 /(R 2+R 3), \quad l d(N O) / d t\} t$ Elux of wo through torch

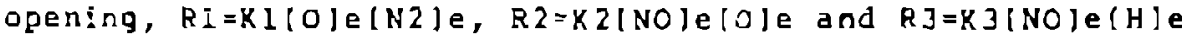

Using the tenperature, pressure and equilibrium values of $0, \mathrm{H}, 02$, oH and $H$ at the end of each crankangle increment, kinetic No formation is calculated by integrating of equation(4). The initial value for No at spark tiaing is assumed to be zero.

To calculate the kinetic co formation, it is assumed that at spark timing. all the carbon in fuel is converted to co which is subsequently oxidized to CD2 during the combustion process via the Eol- 
loring reaction[121;

$\mathrm{CO}+\mathrm{OH}===3 \mathrm{CO} 2+\mathrm{H} \quad K 4=3 * 10+25 \pm \exp \{-600 / 8 \mathrm{~T}\} \operatorname{ce} / \mathrm{mol} \sec (5)$

and the co formation rate is calculated by integrating of the following relation;

$$
\frac{d(\mathrm{CO})}{d t}=\mathrm{K}[\mathrm{OH}](\mathrm{H})+\left.\frac{d(\mathrm{CO})}{d t}\right|_{t}
$$

The product temperature, peesure and the concentration of the specles are assumed to remain as predicted from the full equliltrium nodel. Thus by using the carbon congervation equation;

$$
(\mathrm{CO})+(\mathrm{CO})=(\mathrm{CO}) \mathrm{e}+(\mathrm{CO} 2) \mathrm{e}
$$

The co levels thraugh out the combustion and expansion processes are computed.

\section{5-THEOPETICAL RESULTS ANO DISEUSSIONS}

The computed results Include, NO and co rates of formation, pressure, temperature and mass tzansfer history through the torch opening For both pre and main chambers. The program vas executed for four valueg of equivalence ratio namely $1.1,1.0,0.9$ and 0.8 and an englne speed of 1500 Ipr. The Iesults bere coliected and displayed as two sets ot cuzves. In the first set historjes of prescure, temcerature, nass flou through torch opening and No s co vs. crankangle are presented. Tre second set of curves are a comparison betueen the computej and measizpd values of ko a co emisslons.

snoun in Eigs.(17)through(26) are computational curves of pressure, temperature, mass tou and NO co emissions vs. crankangle. The results are dlsp-ayed for the compression, combustion and expansion phases at an equivalence ratios of 1.1 and 0.8. Fias.(17)and(18)
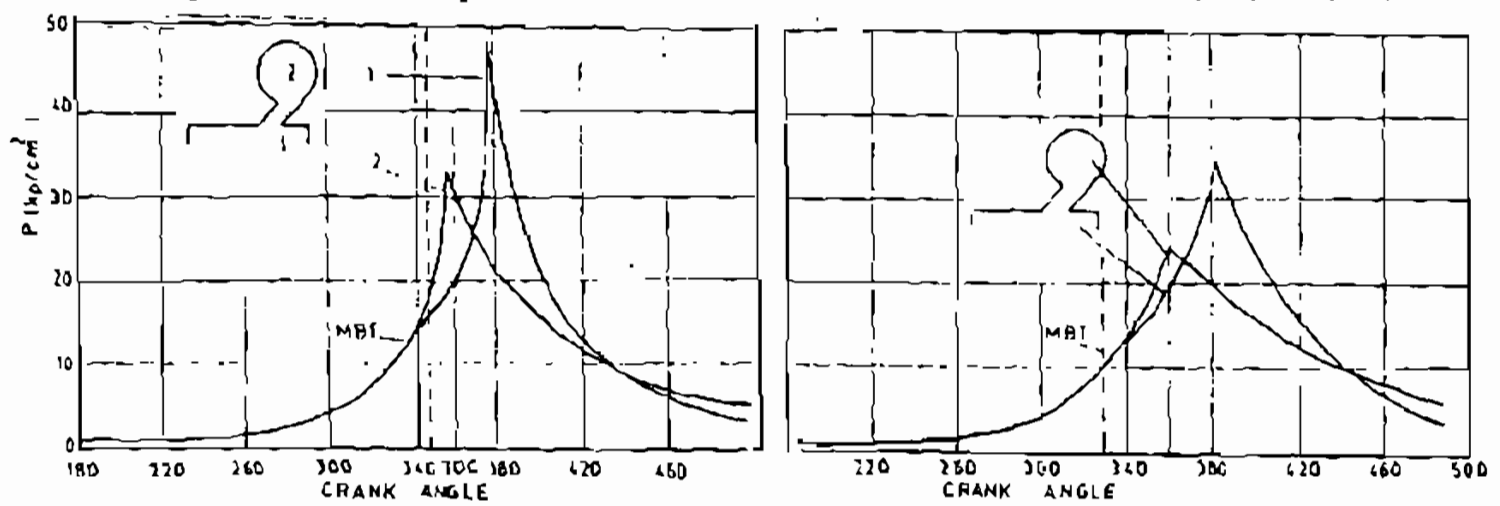

Flgs(17)and(18) Pressure History of Auxiliary and Main Chamberg at Equlvalence Ratios of 1.1 and . 9 Respictively. 
shov the pressure histories for both chambers. It is clear from these flgures that, as the mixture becomes leaner, the peak pressure In both chambers decreases, and the peak pressure in the raln chamber is greater than that of the prcchimber. Il 13 also noticed that the rate of presgure decrease during the expansjon process is faster in the main chamber than that in the prechamber.

Flgs. (19)and (20) shou the teinperature vs. Crankangle dlagrams for both chambers at equivalence ratlos of 1.1 and $0 . \theta$. It can be $=$ een from these flgures that, the temperature levels are alvayg higher in the maln chamber than that in the torch chamber. Also, the maximum gas temperature through the cycle is reached In the main chamber. The results conclude also that, the rate of temperature decrease in the - Dain_chamber is_more rapld than that in the prechamber.
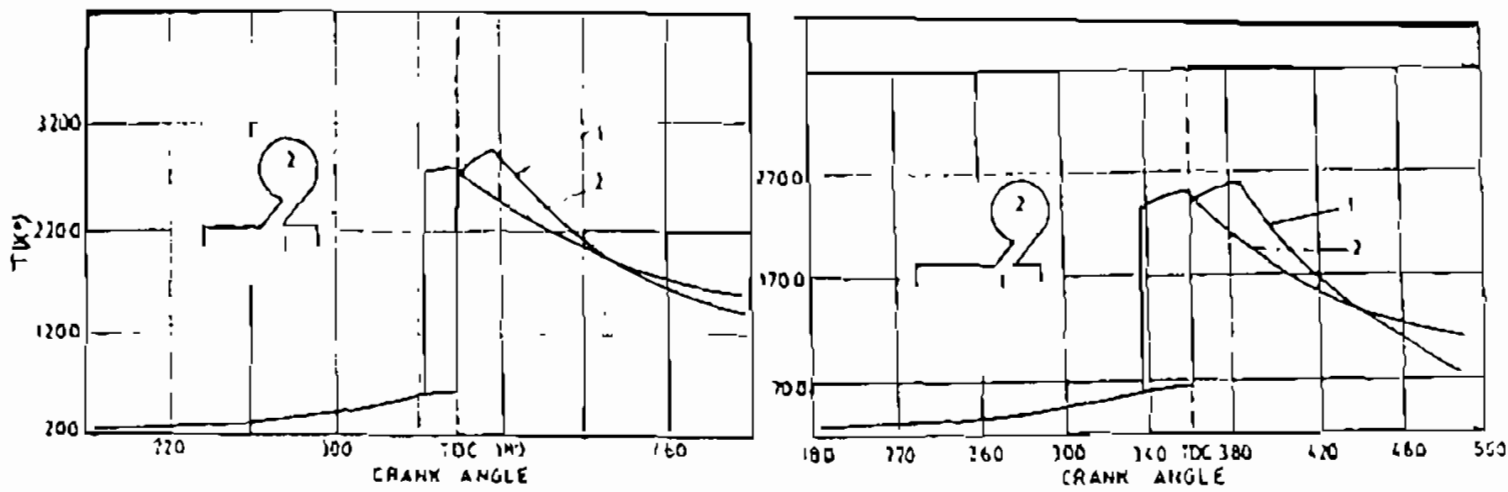

Figs. (I9)and(20) Temperature History Eor Auxiliary and Main Chambers at Equivalence Ratios of 1.1 and. B Respectively.

A history of the mass transfer through the torch opening at eguivalence ratios of 1.1 and 0.8 is shown in Figs.(21)and $(22)$. It is clear from these figures that, early during the combustion process, r.ass transfer. occurs ffrom majo to prechamber oue to the piston motion.
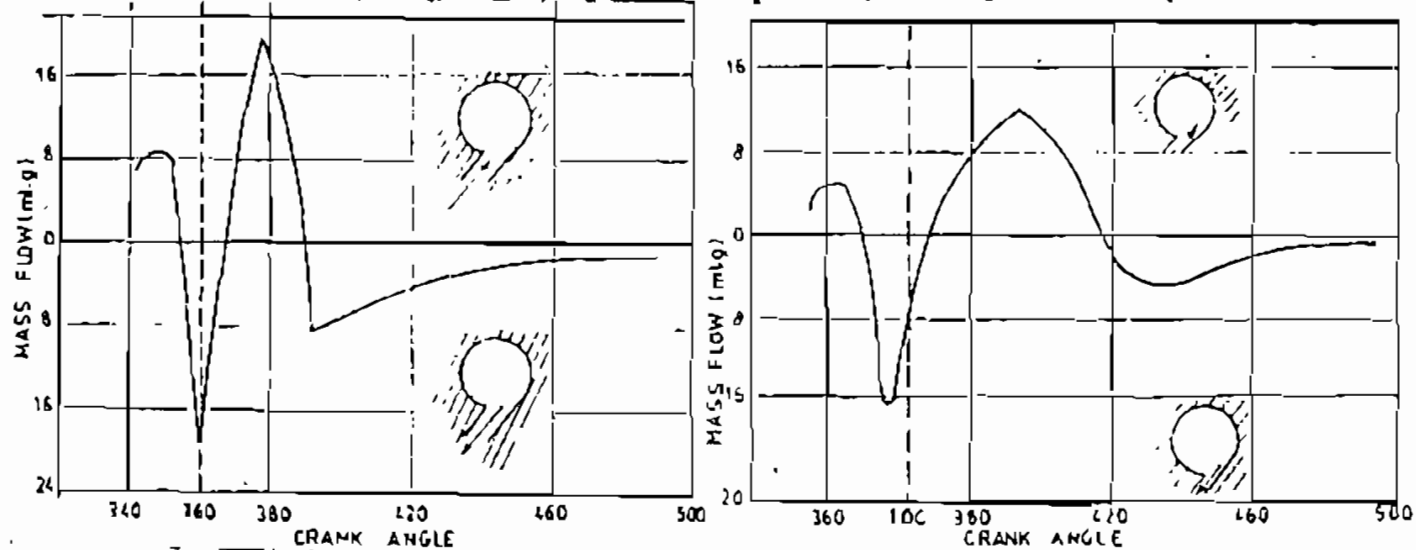

Flgs.i21 Tandi22imass Flov Through Torch Opening vs Crank Angle Degrees at Eguivalence Ratlos of 1.1 and . A Respectively. 
As the pressure In the prechamber r lses due to combustion and exceeds the pressure in the main chamber a reverse flov through the torch opening occurs. Ag the combustion In the maln chamber starts, the rate of mass transer erom pre to maln chamber decreases. As the pregsure in the maln chamber exceeds the pressure in the prechamber, mass transfer from majn to prechamber. During expanslon process, as the presgure In the maln chamber decreages dua to plston motion, the rate OE mags trangfer decreases.

Figs. (23) and (24) 1llustrates the Ho rate of formation in both chambers at equivalence ratios of 1.1 and 0.0 . It is clsar that in easly combustion the ND rate of formation la greater in the main chamber than that in the prechamber. It is also noticed that the formation of No is freezeg later during the expanslon process at a tomperatures of $1950 \mathrm{~K}$ and $1500 \mathrm{~K}$ at equivalence tatios of 1.1 and 0.9 respectively. It can also be seen that, at the end of the expanglon procesa, No slightly decreases in the prechamber and Increages in the main chamber. The results concluded also that the No levels decreages as the mlxture becomes leaner.
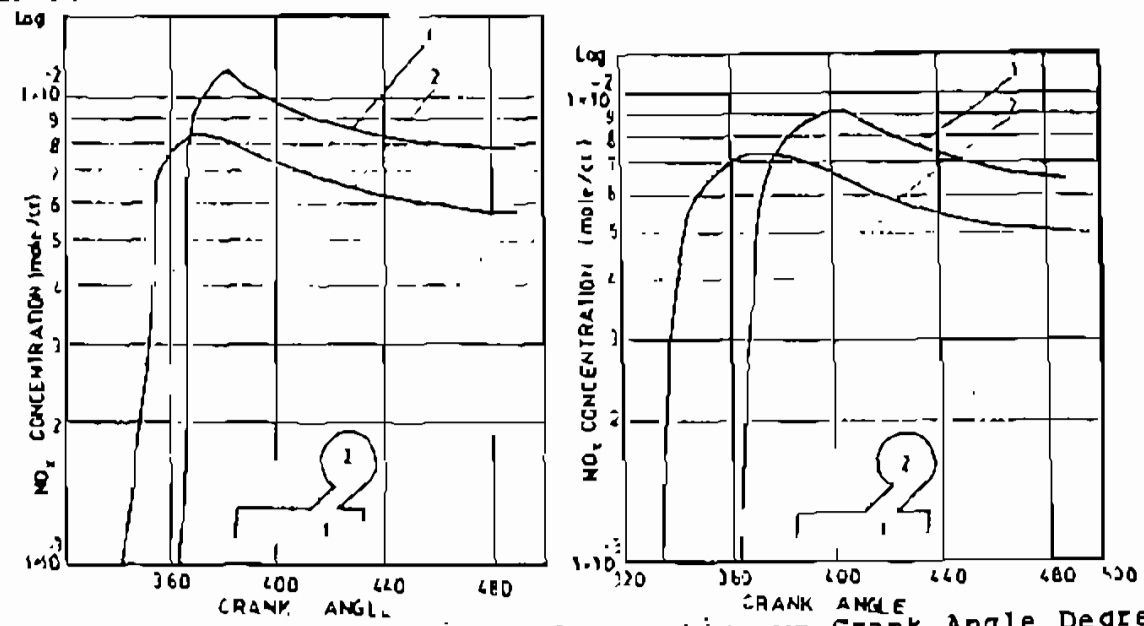

Figa (23) and (24)kinetic Nu Rate of Fornation vs Crank angle Degrees at Equivalence Ratlos of 1.1 and. B Respectively

Flg5.(25)and(26) Illustrates the history of cD formation. It is clear from these fiqures that the rate of co fornation in the maln chamber is greater than that in the prechamber. It 18 also noticed that the co formed In the case of rjch mixture ls greater than that of the lean mixture.

In Figs (27) and (28) a comparison between the measured and calculated values of No and Co emlssions are made. From these curves lt can be concluded that, the calculated value of ro is higher than the measured one. It 15 also noticed that the difference betveen the calculated and measured values increases at lean mixture. This may be due to neglecting the temperature gradient through the burned gares. The same trends are observed for the calculated and measured values of co. 
M. 90 M.M. Awad, A.^. Desoky and A. Nudelkhalck

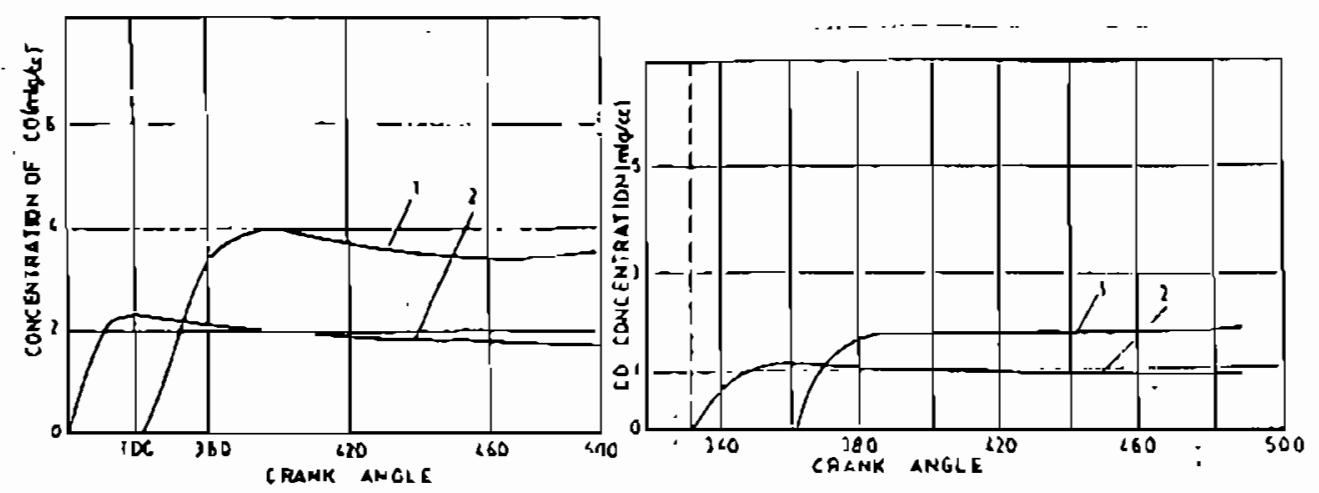

Figs. (25)and(26)kinetlc co Rate of Formation vg Crank Angle Degrees at Equivalence Ratios of 1.1 and .8 Respectively.
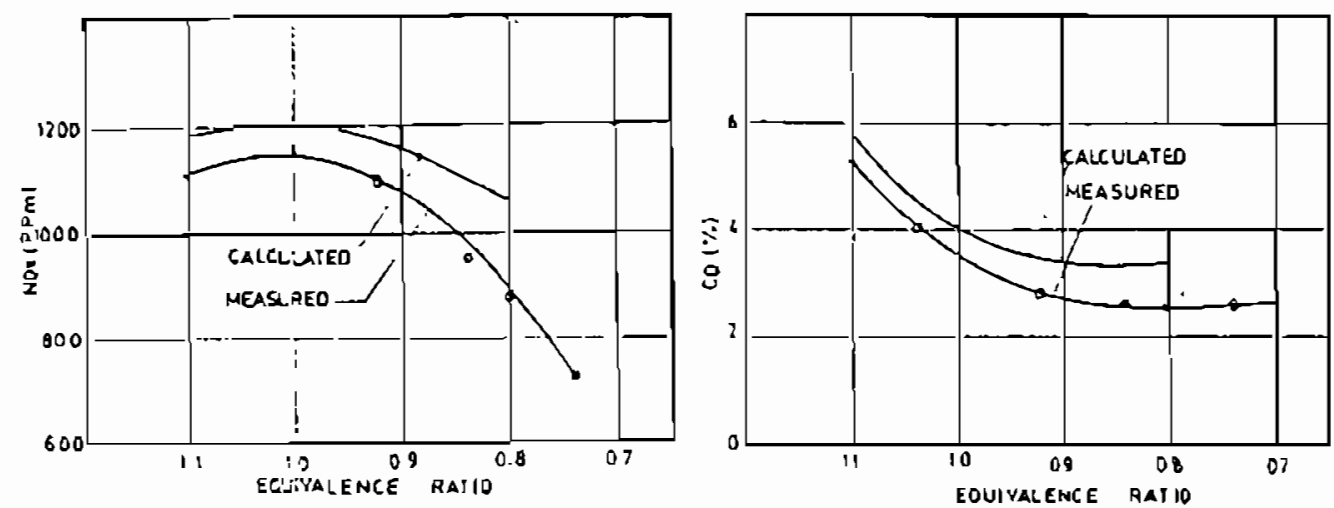

Flgg. (27)and(28)Comparison of Computed and Measured No and Co Respectively vs Equivalence Ratio.

The theoretical results show that, the greatest part of the enission is generated in the main chamber. This may be due to the higher temperature levels in the main chamber. N150, the Erees of No occurs during the expansion process where the temperature is low. This may be due to the small effect of temperature in calculating reaction constant $K 1, K 2$ and $k J$. The slight Increase and decrease in $N O$ and $C O$ in the main and prechamber respectively can be attributed to the Elow through the orifice from the prechamber. The emission trends obtalned from the model at the four equivalence ratios examined here agree ulth the measured values.

\section{6-CONCLUSIONS}

The experimental results give the following conclusions;

1-The use of convergent divergent passage and extended spark gap projection inside the prechamber decreases the englne emisstons allover 
the range of experiments exarined.

2-These advantages are still gained at part load with the cylinder head combination D.

3-Tl:c connecting pasiage shape has"a great effect on LHL of stable operation, while the chL ls less sensitive to lgnition point location. studying the calculated rateg of emlssions formation reveal that,

1-The main chamber is responsible for the formation of the greatest part of engine emissions.

2-The equivalence ratio effects the No and co emission rate of formation.

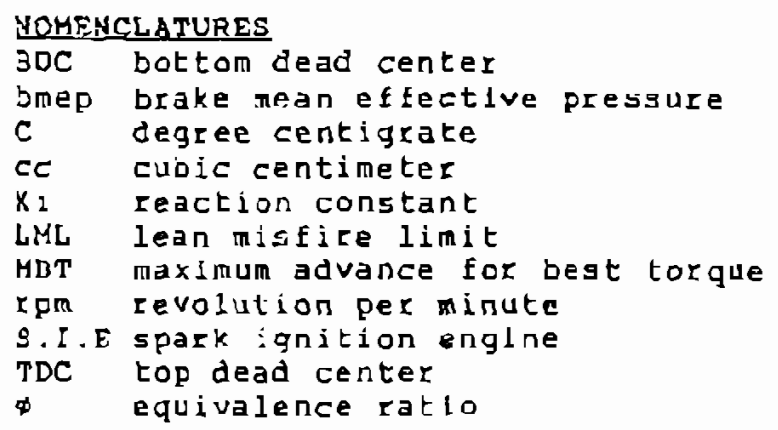

\section{PEFERENCES}

l-Hänel,J.G."Lean Autamative Engine Operation Hydrocarbon Exhaust Emissions and Combustion Charagteristics" gne paper No. 710164 1971

2 Lancaster, R.D. and Kriger, R.B."EfEect of Turbulence on gpark Ignition Engine Combustion" gAE Paper No. 760160, 1976

3-Abas, A. A." Pexformance and Combustion Characteristics of Torch Chamber spark Ignition Engine"M.Sc Thesis, Mansoura University, 1985

4-sinnamon,J.P. and Cole,D.E."The Lneluence of overall Equivalence Ratio and Degree of Charge Stratification on the Euel Consumption anu Emissions of a Prechamber stratificd charge Engine" SAE Paper No. 790438, 1979

5-Adang, T.G. "Torch Ignitlon for Combustion Control of Lean Mixtures" S.A.E. Paper No.790440, 1979, Ford Hotor Co.

6-Adams,T.G."Theory and evaluation of Auxiliary Combustion-(Torch) Chambers" 5.A.E. Paper Ne. 760631,1978 Ford Motor Co.

7-Noguch1,M., Sanda, S. and Nakamuni, O"Development of Toyota Lean Durn Engine"sAE Paper No.760757, 1976 Toyota Motor Co. LTD, Japan

6-Abd-elkalek, A.M."Emission Characteristles of Torch Chamber.S.I.E. gurning Homogeneous Lean Mixture" M.SC Thesis, Mansoura Univ., 1988 .

9 -Shapiro,A.H."The Dynamics and Thermodynamics of Compressible Fluld Flow"John Hileyssons Press, Nev York, 1965

10 Lubln,M.J.and Varde,K.S."The Role of Connecting Nozzle and Flame Initiation Polnt in The Pertormance of a Dual Chamber StratiEied Charge Engineng.A.E Raper No.741101,1974

11 -Tanuma, Takima and Kavasoki"lgnition Combustion and Exhaugt amissions of Lean Mixtures in Automotive SIE"SAEPader 710159.1971 